NBER WORKING PAPER SERIES

\title{
PRIVATE BENEFITS AND CROSS-LISTINGS \\ IN THE UNITED STATES
}

\author{
Evangelos Benos \\ Michael S. Weisbach \\ Working Paper 10224 \\ http://www.nber.org/papers/w10224
}

\author{
NATIONAL BUREAU OF ECONOMIC RESEARCH \\ 1050 Massachusetts Avenue \\ Cambridge, MA 02138 \\ January 2004
}

This paper is based on a talk at the Darden School of Business' Emerging Markets Conference, May 29-30, 2003. We thank Dan Bernhardt, Craig Doidge, Jordan Siegel, Andrew Karolyi, Bill Reese, and participants in presentations at the Darden School, and the University of Illinois for helpful suggestions. The authors can be reached via email at ebenos@uiuc.edu, and weisbach@uiuc.edu. The views expressed herein are those of the authors and not necessarily those of the National Bureau of Economic Research.

(C)2003 by Evangelos Benos and Michael S. Weisbach. All rights reserved. Short sections of text, not to exceed two paragraphs, may be quoted without explicit permission provided that full credit, including (C) notice, is given to the source. 
Private Benefits and Cross-Listings in the United States

Evangelos Benos and Michael S. Weisbach

NBER Working Paper No. 10224

January 2004

JEL No. G3, F3

\section{ABSTRACT}

In this paper, we review the literature on private benefits and cross-listings in the United States. We first discuss the alternative approaches used to measure private benefits. We survey recent evidence documenting cross-country differences in the levels of private benefits obtained by corporate managers, as well as the country-specific factors associated with high and low private benefits. We then explain how, by cross-listing its stock in a market with high disclosure and regulatory standards such as the United States, a firm can commit to a relatively low level of private benefits in the future. We discuss the circumstances under which managers would choose to cross-list their stocks in the United States, when such a cross-listing has important implications for managers' private benefits. Finally, we survey recent empirical work that tests empirical implications of this bonding view of cross-listings. Overall, this evidence provides a compelling case that the desire to protect shareholders' rights so as to facilitate access to equity markets is one of a number of reasons why firms choose to cross-list their stocks in the United States.

Evangelos Benos

University Of Illinois

340 Wohlers Hall 1206 S. Sixth Street

Champaign, IL 61820

ebenos@uiuc.edu

Michael S. Weisbach

University Of Illinois

340 Wohlers Hall

1206 S. Sixth Street

Champaign, IL 61820

and NBER

weisbach@uiuc.edu 


\section{Private Benefits and Cross-Listings in the United States}

\section{Introduction}

Managers' and controlling shareholders' ability to take private benefits from their firms is an important aspect of corporate governance. Firms can raise external finance only to the extent that they can commit to return this capital to investors and not extract it for the managers' personal use. Various laws and institutions provide limits on how much wealth managers can take from investors, and thus make it possible for firms to raise external finance. Thus, there is a logical connection between private benefits and firms' opportunities in the capital market. Not surprisingly, there is a significant relation in the data between the strength of minority shareholders' legal rights and the ability of firms to raise capital [see La Porta et al. (1997)].

Measuring the extent of private benefits accruing to managers and controlling shareholders is therefore a central question in corporate finance, both because the nature of these benefits are interesting and important in their own right, and also because they have a direct impact on firms' access to external capital. A number of recent studies have estimated the level of private benefits, and the extent to which they vary across countries.

These studies have relied on two alternative approaches. First, the analysis of Zingales (1995) suggests that in equilibrium, the value of a vote will be associated with the value of controlling a corporation, and thus with the large shareholders' private benefits. By comparing the prices of otherwise similar high-vote and low-vote shares, Nenova (2002) and Doidge (2003) estimate average private benefits in a number of countries. Second, the analysis of Barclay and Holderness (1989) suggests that private benefits can be measured by the difference between the prices at which controlling blocks change hands, and the prices of minority shares. Dyck and Zingales (2003a) measure the premia of controlling blocks across countries and estimate private benefits in these countries. 
The relation between private benefits and external finance implies that from a manager's perspective, there are costs as well as benefits when resources are taken from shareholders. In particular, when a firm has access to valuable investment opportunities that require external finance, the value of having access to external capital can be large relative to the size of the private benefits. In this circumstance, Stulz (1999) and Coffee $(1999,2002)$ have argued that managers/controlling shareholders will wish to bond themselves not to take private benefits so as to ensure access to external capital markets.

Coffee $(1999,2002)$ has emphasized that one way to perform such bonding is to cross-list the firm's stock on an exchange that imposes higher regulatory and legal costs than the firm's primary exchange. In particular, listing a non-U.S. firm on the NYSE or NASDAQ, either directly or through an ADR, requires registration with the U.S. SEC. Doing so, provides minority shareholders (even those that purchase their shares outside the U.S.) with substantially more legal rights than they have absent such a cross-listing. Doidge (2003), Doidge, Karolyi and Stulz (2003), and Reese and Weisbach (2002) all examine implications of this argument, and find evidence broadly consistent with it.

This paper synthesizes the arguments about private benefits, access to external capital, and cross-listings in the U.S. It discusses in detail the methods used by recent studies, focusing on five particularly important ones: Nenova (2002), Dyck and Zingales (2003a), Doidge (2003), Doidge, Karolyi and Stulz (2003), and Reese and Weisbach (2002). It also summarizes the evidence on a number of questions: Can we measure the value of private benefits? How does this value vary across countries? What country-specific factors lead to larger levels of private benefits? Are there circumstances under which managers would voluntarily choose to commit not to pursue private benefits? How can cross-listing limit private benefits? Is there evidence that commitment to limit private benefits is one reason why firms cross-list in the U.S.? 


\section{Data on Private Benefits and Cross-Listings}

In the past few years, data availability in international corporate finance has improved dramatically. Data on stock prices and returns are available from Datastream, firms' financial data is on Worldscope, and information about security offerings is on the Securities Data Corporation (SDC) database. In addition, the Bank of New York maintains a complete database of American Depositary Receipts (ADRs), and the exchanges' websites contain the identities of firms that cross-list directly.

Table 1 summarizes the construction of the databases for the five recent papers we focus our discussion on, below. More details on the samples' construction can be found in each of the papers themselves. Nonetheless, this table indicates that each study includes a wide variety of countries, and each sample is constructed using data mostly from the 1990s (for reasons of data availability).

\section{Private Benefits}

Private benefits, sometimes called control benefits, are benefits that accrue to managers or shareholders that have control of the corporation, but not to minority shareholders. They can be non-pecuniary, such as the ability to direct a company's resources to a cause one agrees with (Demsetz and Lehn (1985)), a preference for glamorous projects (Jensen (1993)), or the use of a position for the enhancement of one's human capital (Shleifer and Vishny (1989)). Alternatively and more substantially, private benefits can have an enormous direct financial effect on minority shareholders, through transactions that divert corporate resources to other companies owned by the managers or their families. Russian oil companies are the most extreme examples of such 'asset stripping', a consequence of which is that the value (measured as the price per barrel of oil owned by the company) of Russian oil companies is usually a tiny percentage of comparable Western Companies. For example, 
in April 2003, Gazprom, a Russian oil company particularly prone to asset stripping, traded at $\$ .15$ per barrel of oil it owns, about 1 percent of the $\$ 12.38$ per barrel price of Exxon/Mobil at the same time [Dyck (2002)]. ${ }^{1}$

\subsection{Measuring Private Benefits.}

There have been several recent papers estimating private benefits of control internationally, using two alternative approaches. The methods used by these papers are summarized in

\section{Table 2.}

The Control Block Approach. One approach to measuring private benefits was originally proposed by Barclay and Holderness (1989), and relies on ownership changes of controlling blocks of shares. Barclay and Holderness argue that the difference between the price per share paid by the acquiring party and the price per share prevailing on the market after the acquisition has taken place will reflect private benefits associated with the control of that company. This difference is a plausible measure of private benefits since the price per share paid by the acquiring party reflects not only the expected future cash flows but also the value of control, whereas the market price of the shares reflects only the cash flow benefits.

Extending the Barclay/Holderness approach to an international context, Dyck and Zingales (2003a) calculate the control (or block) premium in 393 control- transfer transactions spanning 39 countries for the years 1990-2000. These authors define the block premium as:

$$
\text { Block Premium }=\lambda B_{b}+(1-\lambda) B_{s}-\alpha(1-\lambda)\left(Y_{b}-Y_{s}\right) \text {, }
$$

\footnotetext{
${ }^{1}$ Examples of private benefits taken by managers are extremely common in business press, and sometimes outrageous. One recent blatant example occurred at Hollinger, Inc., where the chairman, Conrad Black, paid $\$ 12$ million of the corporation's money to purchase thousands of historical documents about Franklin Delano Roosevelt to help in the preparation of a book that he personally was writing about the former president. When asked why he used Hollinger's money rather than his own, Black responded that the \$12 million 'was not something I was prepared to spend'. [See MacLeans, September 1, 2003]
} 
where $\mathrm{B}_{\mathrm{s}, \mathrm{b}}$ is the level of private benefits extracted by the seller (buyer), $\mathrm{Y}_{\mathrm{s}, \mathrm{b}}$ is the seller's or buyer's level of cash flow benefits per share, $\lambda \in[0,1]$ represents the bargaining power of the controlling shareholder selling his shares and $\alpha \in[0,1]$ are the cash-flow rights or the size of the controlling block. This number is the aggregate price differential that the buyer pays the seller. For the case where $\lambda=1$, i.e. the seller has all the bargaining power, the block premium reduces to $\mathrm{B}_{\mathrm{b}}$ implying that the buyer pays the seller the entire value of private benefits. Dyck and Zingales rely on this case, implicitly $\lambda=1$, and estimate the following regression: $B P / Y_{b}=\alpha($ Country Dummy $)+\beta($ deal char $)+\gamma($ buyer-seller char $)+\delta($ industry char $)+\varepsilon$

To make cross-country comparisons of the level of private benefits, these authors control for differences in the characteristics of the block trades, differences in firm and industry characteristics, differences in investor legal protection in the acquirers home country and whether the target firm is cross-listed. Once these factors are controlled for, the coefficient of the dummy variable for each country is an estimate of the private benefits associated with a typical firm in that country.

One limitation of this approach is that it implicitly assumes that the private benefits associated with the firms in which a block is traded are the same as they are for firms in which blocks are not traded. Without a structural model of the supply and demand for private benefits in firms, it is hard to tell if this selection issue will lead to an overestimate (if blocks change hands when benefits are large because new buyers have a large demand) or an underestimate of private benefits (if blocks are unlikely to change hands whenever benefits are really large). Nonetheless, this selection issue should be kept in mind when this method is discussed. 
The Voting Approach. The second way of measuring private benefits is to calculate the percentage difference in the price of shares with different voting rights but same dividend rights. This voting premium can then be used as an alternative estimate of private benefits.

It is important however to understand the theoretical linkage between private benefits and the voting premium at a firm as outlined by Zingales (1995). The price differential between different classes of shares reflects not only the magnitude of private benefits that the controlling party is enjoying, but also the probability that a vote will be pivotal in a control contest. A vote that is unlikely to be pivotal will have low value, even if control is associated with high private benefits. The likelihood of a control contest depends then on the firm's ownership structure; the more concentrated the ownership, the less it is likely that some control contest will take place. Therefore, a limitation of the Voting Premium approach is the fact that the voting premium is likely to be strongly related to the market's assessment of the probability of a control contest in the future.

In addition, selection issues are also present with the voting premium approach. The mere existence of dual class shares is likely to be correlated with higher private benefits since empirical work suggests that controlling shareholders typically control the voting rather than the non-voting shares (see DeAngelo and DeAngelo 1985). Thus, the voting approach could potentially overstate the level of private benefits, since the samples of studies based on dualclass firms are prone to include a disproportionately large number of firms with large private benefits.

Doidge (2003) and Nenova (2003) both use the voting approach to estimate the private benefits accruing to managers in different countries. Doidge estimates the voting premium as his measure, while Nenova uses an adjustment for shares outstanding in each class to estimate the control benefits.

Doidge estimates the voting premium as: 
In this formulation, $P_{H}$ and $P_{L}$ are the weekly local market closing prices of high and low voting shares and $r v$ is the relative number of votes attached to the low voting shares (between 0 and 1). Intuitively, this measure reflects the price difference per vote. ${ }^{2}$ Doidge does not control for either the likelihood of a control contest or for any other factors. This lack of controls should be kept in mind when comparing his estimates of private benefit magnitudes to those from other studies.

Nenova's approach is to estimate the value of a control block votes as:

$V C B V=\left[P_{M}(t)-P_{L}(t)\right] /(1-k) *\left(\left[N_{M}+N_{L} * k\right] / 2\right) /\left[N_{M} * P_{M}(t)+N_{L} * P_{L}(t)\right]$

where $P_{M}(t), P_{L}(t)$ are the weekly prices of multiple and limited voting shares, $N_{M}$ and $N_{L}$ are the numbers of multiple and limited voting shares and $k$ is the ratio of the voting power of a limited voting share to that of a multiple voting share. By this approach, Nenova attempts to capture the value differential not of a single vote but of a controlling block of shares. Intuitively, the value of a marginal vote depends on the relative number of shares in each class and so she has to control for this factor. This approach requires that an assumption be made about how "big" a controlling block is. Nenova assumes that control requires $50 \%$ of the vote, and thus multiplies her estimate by one half of the total voting power (factor $\left.\left[N_{M}+N_{L} * k\right] / 2\right)$. Finally, to control for firm size she divides her voting premium measure by the total market value of the firm (factor $\left.N_{M} * P_{M}(t)+N_{L} * P_{L}(t)\right)$.

Because she is interested in cross-country comparisons, Nenova estimates a regression similar to that of Dyck and Zingales to control for the probability of a vote being demanded during a control change, and the differences in dividend payments and in liquidity

\footnotetext{
${ }^{2}$ Note that in the common case of the low voting shares having no votes at all, this equation reduces to $\left(\mathrm{P}_{\mathrm{H}}-\right.$ $\left.\mathrm{P}_{\mathrm{L}}\right) / \mathrm{P}_{\mathrm{L}}$, or the percentage difference in price relative to the low-voting class.
} 
between the classes of shares. The country effects are the coefficients on country-specific dummy variables in the following regression:

$V C B V=\alpha($ Country Dummy $)+\beta($ Shapley value $)+\gamma(\log$ Firm Size $)+\delta($ Dividend Ratio $)+$ $\varepsilon($ cumulative $L V$ dividend $)+\zeta($ Registration Costs for $M V)+\eta(\log$ difference in turnover $)(5)$

The Shapley value of a voting game, which is intented to reflect the value of control to the participating players (i.e. the extend to which each player's vote is expected to be pivotal), is used as a proxy for the probability of a control contest. ${ }^{3}$ Firm size is defined as firm's market value scaled by the stock market capitalization of its country. The dividend ratio between low and high voting shares captures the differences in cash flow benefits, while the cumulative LV (low vote) dividend variable is a dummy that takes the value 1 if dividend payments to a limited voting share are cumulative. The "Registration Costs for MV (multiple vote)" variable is also a dummy that equals 1 if the multiple voting class of shares has registration costs that do not apply to the limited voting class. Finally, the difference in turnover defined as: limited voting turnover/ multiple voting turnover accounts for differences in the liquidity of the two classes of shares.

\subsection{Cross-Country Estimates of Private Benefits}

The estimates of private benefits in each country are presented in Table 3. In general, estimates of private benefits are correlated across studies, suggesting that each approach is measuring the same thing. For example, in countries like Brazil, Italy, and South Korea, each approach leads to relatively high measures of private benefits, while in the U.S., Norway, and Sweden, the estimates of private benefits are fairly low. On the other hand, there are some countries like Mexico and Switzerland, where there is reasonably high variation across approaches.

\footnotetext{
${ }^{3}$ For an introduction to Shapley Value, see Appendix A of Chapter 18, in Mas-Colell et al. (1995).
} 
The results summarized in Table 3 indicate that countries vary widely in terms of managers' abilities to extract private benefits. What leads private benefits to be so small in some countries and so large in others? These papers perform cross-sectional analyses to isolate the factors affecting the ability of managers to take private benefits.

Legal Environment. Consistent with the analysis of La Porta et al. (1998), the most important factor explaining the level of private benefits is the legal environment in which this firm operates. Controlling shareholders all over the world maximize their own utility; what differs across countries are the legal restrictions they face that limit their ability to do so. The better the minority shareholders are protected, the more difficult it is for controlling shareholders to expropriate value from them. Minority shareholder protections include the ability to sue the management, strict disclosure, high accounting standards, and takeover laws that ensure that in the event of a control transfer, minority shareholders receive a proportional share of the control premium.

Dyck and Zingales (2003a) and Nenova (2002) verify that in fact, private benefits are related to these variables. For example, Dyck and Zingales find that a one standard deviation increase in accounting standards (as measured by the CIFAR index), reduces the value of control by $9 \%$, a one standard deviation increase of an anti-director rights index reduces the value of control by $4.4 \%$, and a one standard deviation increase of law enforcement (as measured by the IBR index) decreases the value of control by 7\%. Similarly, Nenova estimates that in her sample, the value of control block votes is $48 \%$ with the worst observed levels of the shareholder protection variables (Law enforcement, Investor protection, Takeover Law, Corporate Charter provisions), and is reduced to $5 \%$ with the best levels. In addition, each of these variables has a negative coefficient in a regression using the value of control block votes as the dependent variable. Finally, Nenova finds that the value of control block votes is larger in French Civil Law countries (which generally provide relatively weak 
investor protection) than it is in British Common Law countries (which provide relatively strong investor protection).

Emerging Markets. An interesting question concerns whether private benefits are larger in emerging markets, or developed markets. While this question is not addressed directly in the papers we focus on, we can supplement the analysis in these papers by comparing their estimates of private benefits across countries.

To do so, we rely on the International Finance Corporation (IFC) classification scheme utilized by Lins, Strickland, and Zenner (2003). The IFC classifies 22 of the countries listed in Table 3 as emerging and 16 as developed. Since the Dyck and Zingales paper contains private benefit estimates for most of the countries, we report comparisons using these estimates, but the results are similar using the Nenova or Doidge estimates. Dyck and Zingales find that for the 22 emerging market countries, the average private benefit level is $18.1 \%$, while for the 16 developed market countries, the average level is $3.8 \%$. This difference is statistically significant using standard tests of means. The large difference in private benefits across countries suggests that it is substantially easier to expropriate private benefits in emerging markets than in developing ones.

Other factors. In addition to the legal environment, there are other factors that affect the size of private benefits. Such factors include product market competition, public opinion pressure, the nature of the media, and the quality of tax enforcement. Product market competition makes prices more accurately reflect cost, making it difficult to extract firm value through manipulated transfer prices. In addition, recent research suggests that both public opinion and the media exert pressure on managers to behave according to the prevailing social norms, implying that the magnitude of their effect on private benefits can be large or small depending on the social norms of a given country (see Dyck and Zingales 2003b). Finally, to the extent that controlling shareholders might be using transfer prices to 
extract private benefits, enforcement of tax rules that regulate transfer prices should curb private benefits (Desai, Dyck and Zingales (2003)).

Dyck and Zingales (2003a) verify empirically that these extra-legal factors have indeed a significant effect on the magnitude of private benefits. In a univariate analysis, they find that a one standard deviation increase in their measure of market competition reduces the value of control by $6 \%$ and that competition explains $20 \%$ of the cross-country variation in private benefits. A one standard deviation increase in the diffusion of the newspapers, decreases the value of control by $6.4 \%$ while a one standard deviation increase of their tax compliance measure curtails the value of control by 8.6 percentage points. In a subsequent multivariate analysis all of the variables retain their sign but only tax compliance and newspaper diffusion remain significant.

\subsection{Private Benefits' Impact on Financial Development}

The quantity of private benefits managers receive has a large impact on financial development. In countries with large private benefits, entrepreneurs will receive on average a substantially lower price for their firms in the public market conditional on the same cash flows than they would have received in a market with lower private benefits. As a consequence, high private benefits imply that the threshold for going public will be higher, and we will observe fewer firms that are more mature having a public market for their securities. In addition, minority positions will sell for relatively low prices because of the risk of expropriation by the majority shareholders. Hence, in countries with large private benefits, fewer companies' securities will trade on public markets, and the capitalization of the equity market relative to the GDP should be small.

In addition, since entrepreneurs are more likely to retain control even after they list their company, we expect few companies to be widely held. Finally, in countries with high private benefits, a revenue-maximizing government should prefer to transfer control of state- 
owned firms via private negotiations rather than public offerings, since the price received in a negotiation will reflect the control benefits, while the price in a public offering will not.

Dyck/Zingales examine these propositions empirically. They find that in countries

with high private benefits, ownership is more concentrated, governments avoid selling firms in public offerings and the equity market is less developed. Their econometric work implies that a one standard deviation increase in the size of private benefits, measured by the Block Premium, leads to $11 \%$ more equity being held by the three largest shareholders, to $36 \%$ more firms being privatized through private negotiations and to a $67 \%$ decline in the proportion of external equity capitalization over GNP.

\section{The Bonding Hypothesis}

\subsection{The Demand for Bonding}

Consider the situation facing managers of a firm when the legal system does not protect shareholders well and, as a consequence, private benefits are high. While the managers enjoy private benefits, their firms face restricted access to capital markets. Their firms cannot accept all positive net present value projects that they have access to, and to the extent that managers own substantial stakes in their firms (typically true in high privatebenefit countries), the managers themselves lose their portion of the projects' net present value.

The manager of a firm with access to a valuable investment opportunity faces somewhat of a dilemma. The private benefits he enjoys prevent him from accessing the capital market, and hence from reaping the positive net present value of the project. If he could somehow commit to forego taking private benefits personally (and convince potential investors of this commitment), he could then undertake the project and reap his share of the 
net present value. By this logic, if the project were sufficiently valuable, then it would make sense for managers to 'bond' themselves to avoid taking private benefits.

\subsection{Cross-Listings and Private Benefits}

In a country with a weak legal system, or one that favors controlling shareholders relative to minority shareholders, it is potentially difficult to think of 'bonding devices' that would be persuasive to potential outside shareholders. After all, once their investment is sunk, investors' only recourse is to a court system that typically works against investors. However, Coffee (1999) and Stulz (1999) have suggested that one way to persuade investors (at least partially) to invest in a such a firm, is to cross-list the firm's equity on an exchange of a country that does protect minority shareholders well.

A foreign company can either list its shares on a US exchange directly, or it can list via an American Depositary Receipt (ADR) program. ADRs are negotiable certificates of ownership of outstanding shares of a foreign firm traded in the US markets. An ADR holder has all the voting and dividend rights stemming from the underlying shares, the shares themselves being deposited in a Depositary Bank in the firm's home country. These Depositary banks convert all dividends and other cash flows into US dollars and charge a small fee.

Coffee $(1999,2002)$ emphasizes that regulations associated with cross-listing in the United States have significant regulatory and disclosure implications for a company listing its stock on an organized exchange. These implications vary with the type of listing that firms choose; listing on an organized exchange is generally associated with similar regulatory and disclosure requirements to those faced by U.S. firms, while over-the-counter listings entail minimal requirements.

Depositary receipts fall into several different categories, each of which has a different regulatory burden. Firms wishing to have their depositary receipt traded on the NYSE or 
Nasdaq must list via a "Level 2 or 3" ADR, in which case they are subject to similar requirements with those firms that cross-list directly. Level 2 ADRs are traded on a US exchange but cannot raise issue equity in the U.S. Issuers of Level 2 ADRs are required to register and file Form 20-F reports with the SEC and reconcile their accounting with US GAAP. Level 3 ADRs are traded on an exchange as well, and are allowed to raise equity in the U.S. These issuers are subject to full SEC disclosure, compliance with US GAAP, and registration on Form F-1. Both Level 2 and Level 3 ADRs are subject to the provisions of the Securities Exchange Act.

If a firm does not wish to have its stock trade on the NYSE or Nasdaq, there are two options that are far less costly from a regulatory perspective. If a firm uses a Rule 144a $\mathrm{ADR}$, its regulatory requirements are minimal, but its security can only trade among registered institutional traders. Finally, firms can issue Level 1 ADRs, which trade over-thecounter as "Pink Sheet" issues, and have little disclosure or accounting requirements.

Panel B of Table 4 summarizes the additional regulatory requirements associated with a Level 2 or Level 3 cross-listing, which is associated with SEC registration. ${ }^{4}$ These restrictions comprise some of the most important governance provisions faced by U.S. firms. Two particularly important provisions are the right of shareholders to file $10 \mathrm{~b}-5$ suits under U.S. law rather than foreign law, and the requirement that accounting must comply with U.S. GAAP.

Other than the possibility of shareholder suits and accounting changes, the effectiveness of bonding through cross-listings depends on the degree of SEC enforcement of these rules. Licht (2003) argues that the SEC “cuts corners" on corporate governance rules for foreign issuers and generally has a "hands off" policy towards these firms. Undoubtedly, Licht must be correct to some extent; it is hard to imagine the SEC enforcing governance

\footnotetext{
${ }^{4}$ See Coffee (1999) for much more detail about these requirements.
} 
regulations to the same degree against a non-U.S. company as they do to a U.S. company. However, the regulations are on the books nonetheless, and it is at least plausible that they are enforced some of the time, and, more importantly, that investors assign a positive probability that they will be enforced in the future.

Siegel (2002) attempts to assess the SEC enforcement policy towards foreign firms listing in the U.S., by considering its actions towards Mexican firms with ADRs during the years 1995-2002. He finds that in all cases of asset tunneling, US institutional response has been weak, as the SEC did not take any action to recover the billions of dollars taken from US investors. For the same period he finds only 13 legal actions against foreign firms in general, and concludes that SEC enforcement does not have a meaningful impact for nonU.S. firms listing in the U.S. Siegel emphasizes the reputational consequences of crosslisting, rather than the legal ones.

To us, the essence of the question, however, is not whether we can measure the degree of actual actions done by the SEC or not or if the SEC treats offenses by foreign firms the same as it treats those by domestic firms. The issue of economic importance is whether managers and investors perceive cross-listings to have incremental protection or not. To examine this proposition, the appropriate approach is not to count SEC actions and debate whether they are important or not. Rather, it is to examine the data for empirical implications of the hypothesis that cross-listings provide incremental protection, and therefore serve as a device enabling managers of non-U.S. firms to commit to protect the interests of their minority shareholders. This is the approach taken by Doidge (2003), Doidge, Karolyi and Stulz (2003) and Reese and Weisbach (2002).

\subsection{The Geography of Cross-Listings}

The patterns that appear in cross-listings around the world, and the way these patterns change over time, are useful starting points of any discussion trying to identify what explains 
the firms' cross-listing behavior. One feature of international cross-listings is that they tend to be clustered among countries that are close to each other, and also have similarities and historical ties. For instance, most of the cross-listed firms in Vienna's stock exchange are German and a large number of European firms cross-listed on US exchanges are British.

Sarkissian and Schill (2003) show that factors such as common language, colonial ties, trade relationships and similar industrial structure are important in explaining the selection of a cross-listing destination. Pagano et al. highlight the importance of investors' ability to assess information, as they emphasize: “...for a US investor, the accounting data and the performance of a British company, are easier to decipher than those of a French or Spanish company".

An even more important pattern however, is a dramatic increase in the number of European firms listing in the US, which is likely to be related to the failure of European markets to attract new listings during the nineties. The reason why this pattern is important, is twofold: First, the European companies that have cross-listed in the US are high-tech export oriented firms that rely on equity funding to pursue a rapid expansion (Pagano et al. 2002). Second, they are firms from countries whose markets are generally perceived as liquid. This implies that the US exchanges have been for some reason, other than liquidity, better able to satisfy the demand for equity capital.

Table 5 (taken from Pagano et al. 2002) summarizes the numbers of European and American cross-listed firms on the major US and European exchanges in the years 1986, 1991 and 1997. Although in 1986 there were more than five times as many American firms listed on European exchanges than European firms listed in the US, in just a decade the pattern reversed and the European companies listed in the U.S. became more than the U.S. companies listed in Europe. This relation is likely to be part of a general phenomenon, a consequence of which is that European exchanges failed to attract domestic listings as well. 


\subsection{Empirical Implications of the Bonding Hypothesis.}

The bonding hypothesis suggests that one reason why firms should cross-list in the United States is to protect minority shareholders from managers consuming private benefits, and to facilitate their access to capital markets. Of course, there are many other reasons why firms may cross-list their stock on other markets. These reasons have been well surveyed by Karolyi (1998), and involve both financial and "informational" benefits that result from overcoming market segmentation and reducing informational asymmetries. First, crosslistings lower the cost of capital as they expand a firm's shareholder base, spreading the firm's risk over a greater number of investors who, in turn, demand a smaller premium. Also, cross-listings ease credit constraints by providing access to the large and liquid US capital market.

Karolyi (1998) also discusses a number of information-related potential advantages associated with cross-listing. To the extent that trading on capital markets provide general visibility, trading on a US market potentially could affect US sales of a firm's products. The mere act of cross-listing could conceivably signal that a firm is of high quality since doing so would convey to the market that the firm satisfies the eligibility criteria for cross-listing and is willing to subject itself to the strenuous disclosure requirements that are involved (Cantale (1997)). The existence of a body of well-informed analysts may be an additional reason for companies, especially in high-tech areas, to cross-list (Lang, Lins and Miller (2003). These analysts are experts in evaluating the companies' growth opportunities and can significantly affect a company's amount of equity finance by shaping investors' opinions.

The bonding hypothesis is not mutually exclusive from these other arguments. However, it does have a number of implications that do not arise from these more traditional explanations for cross-listing. These predictions are summarized in Table 6. 
Cross-listing and Shareholder Protection: According to the bonding arguments, firms crosslist when they have good investment opportunities and wish to access external capital markets to undertake these investments. Clearly, this reason is more relevant for firms from countries where there is poor protection; the incremental protection from cross-listing would not be important if shareholders' rights were already well-protected. However, if a firm that does not have good investment opportunities is considering cross-listing for a reason other than bonding, the fact that a cross-listing increases shareholders' rights will make a crosslisting less attractive because managers would lose their private benefits with no offsetting advantage. Therefore, private benefits will lead firms that do not have good investment opportunities to be less likely to cross-list. Overall, the relation between shareholder protection and the number of cross-listings is likely to be strongly dependent on firms' demand for external capital; without knowing this demand it is possible for cross-listings to be either increasing or decreasing in shareholder protection. ${ }^{5}$

Cross-listing and Firm Value: If firms cross-list at least in part to limit private benefits and to access capital markets, then there are strong predictions about the relation between crosslisting and firm value (see Doidge, Karolyi, and Stulz (2003)). First of all, the firms that cross-list will be more likely to have good investment opportunities than otherwise identical firms that do not cross-list. Therefore, we expect that other things held constant, firms that cross-list have more growth opportunities and higher values prior to the cross-listing. In addition, after the cross-listing occurs, not only do expected private benefits decrease for the cross-listing firms, but also new growth opportunities are now worth more since cross-listed firms can better exploit them. So this difference in value should increase at the time and after the cross-listing. Finally, both of these effects should be larger when a firm is from a country

\footnotetext{
${ }^{5}$ See Lombardo and Pagano (2000) and Doidge, Karolyi, and Stulz (2003) for related arguments.
} 
with poor protection and high private benefits. If a firm with a high level of private benefits cross-lists its stock, then this firm must have growth opportunities sufficiently high to offset the large private benefits in that country. Therefore, we expect the difference in value between cross-listed and non-cross-listed firms to be larger for firms when home country protection is poor.

Cross-listing and Private Benefits: We expect a cross-sectional relation between private benefits and cross-listing for two reasons: First, we have argued that a cross-listing lowers private benefits by increasing shareholders' rights. At the time of cross-listing, observed private benefits should decrease, leading, for firms with dual classes of stock, to a drop in the price difference between the high-vote and low-vote shares. Second, firms that have a proclivity for high private benefits have more to lose from cross-listing, so they are less likely to cross-list. Therefore, we expect that firms which have the highest levels of private benefits will be the least likely to cross-list their stocks, so that cross-listed firms should have lower observed levels of private benefits.

Cross-Listings and Access to Equity Capital: If cross-listings occur at least in part for the reasons emphasized by the bonding arguments stressed above, then we should observe firms raising capital following cross-listings. The protections associated with SEC registration apply more to equity than debt, so we expect firms to issue equity following cross-listings in the U.S. Of course, if firms list their stock in the U.S. to access new markets independent of any effect on private benefits, we would also expect an increase in equity offerings. However, the bonding argument has an additional prediction from the "access to capital" argument; the bonding argument implies that the increase in equity offerings should be larger from countries with weak protection. In contrast, the access to capital argument makes no prediction about shareholder protection in the home country. Thus under the bonding 
hypothesis, once a firm from a country with weak investor protection has cross-listed, it is more likely to issue equity than a firm from a strong protection country.

In addition, we expect shareholder protection in the home country to affect the location of the offerings. When the offering is from a country with strong protection, we expect firms to access U.S. markets to raise capital from U.S. investors. We expect such a relation because firms from countries with strong protection have no inherent difficulty in raising capital at home, so when they cross-list in the US, they do so to access US capital markets. In contrast, when the offering is from a country with weak protection, we expect firms to be more likely to cross-list in the U.S. and then raise capital at home (or in a third country outside the U.S.) because one reason for the cross-listing is to improve protection for all shareholders, including those outside the U.S. Shareholder protection arising from SEC regulations acts as a public good. Firms from outside the U.S. take advantage of this protection to commit to investors both in the U.S. and outside of the U.S. that the firm's managers will not seize private benefits after the capital has been raised.

\subsection{Empirical Evidence on Bonding}

The implications of the bonding argument discussed above have all been tested in a number of studies. Next we survey this empirical work, and discuss the empirical relations that have been documented between cross-listings and each of: shareholder protection, firm value, private benefits and access to equity capital. Finally, we discuss the empirical evidence on stock price reaction to cross-listings and we relate these findings to the bonding argument. Cross-listings and shareholder protection: Reese and Weisbach (2002) examine the relation between the number of cross-listings and the level of shareholder protection in the crosslisted firms' home country, using a sample of 2038 firms between 1985 and 1995. Univariate statistics show that on average a higher proportion of firms from French Civil Law countries (assumed to provide weaker shareholder protection) cross-list on the NYSE or Nasdaq than 
firms from English Common Law (10.1\% vs. $7.4 \%)$. These listings on NYSE or NASDAQ are most relevant for the bonding arguments because they require firms to register with the SEC while OTC cross-listings do not. Thus, these results are suggestive that firms from countries with weak shareholder protection bond themselves to protect shareholder interests by listing in the United States.

However, in a subsequent multivariate analysis where the level of shareholder protection is proxied for by the country's legal system, an anti-director rights index and an accounting standards index, the same results are reversed when they control for potentially important factors such as firm size, the home country's GNP and whether the home equity market is developed or not. Reese and Weisbach argue that this difference is probably due to the presence of the control variables, since larger firms are more likely to cross-list and French Civil Law firms tend to be larger than English Common Law firms. Overall, the empirical evidence on this point is somewhat mixed, which is not surprising given the ambiguous theoretical predictions.

Cross-listings and Firm Value: The relationship between firm value and cross-listing is examined in great detail in Doidge, Karolyi, and Stulz (2003). In a sample of 714 cross-listed and 4078 non-cross-listed firms from 40 countries, Doidge, Karolyi and Stulz find that on average, firms that are cross-listed in the United States have a $16.5 \%$ higher Tobin's q ratio than firms that are not cross-listed. In addition, this cross-listing premium is much higher for firms listed on a US exchange (36.5\%) than firms listed via rule $144 \mathrm{a}(14.2 \%)$ or over the counter (4.5\%). This relation also holds in a multivariate regression analysis.

Doidge, Karolyi and Stulz also find that the cross-listing premium is robust after controlling for a firm's growth opportunities (as measured by the sales growth in the past two years and the median q of the industry to which the firm belongs) and country specific variables like the type of legal system, as well as measures of "anti-director rights", 
accounting standards, judicial efficiency and liquidity ratio. Finally, also consistent with the bonding hypothesis, they provide evidence in a series of regressions that the cross-listing premium effect is larger for countries with weak shareholder protection.

Comparing the effect for emerging markets and developed markets, Doidge, Karolyi and Stulz's findings suggest that the difference in $q$ is slightly larger for emerging markets than for developed markets (.23 for emerging markets vs. .20 for developed markets). However, the difference between emerging and developing markets is not significantly different from zero.

Cross-listings and Private Benefits: Doidge (2003) provides the best estimates on the relation between cross-listings and private benefits, and suggests that cross-listed firms exhibit substantially lower levels of private benefits than non-crosslisted firms. Doidge uses the voting premium approach to estimate private benefits in a sample of 745 firms with dualclass voting shares. Of these 745 firms, 137 are cross-listed in one of a number of ways (Rule 144a, Level 1, 2, 3 ADR). The observations are from 20 countries and span the years 1994-2001. To isolate the effects of cross-listings only on the voting premium, he controls for firm-level variables like differences in voting power, dividends, liquidity and firm size, as well as country-level variables like minority shareholder rights, disclosure environment, system of legal enforcement and ownership concentration. The (random effects) regression equation is:

$$
V P_{i t}=\alpha+\gamma_{1} L 144 a_{i t}+\gamma_{2} L 1_{i t}+\gamma_{3} L 2 / 3_{i t}+b x_{i t}+d c_{i}+\mu_{i}+e_{i t}(6)
$$

where $V P_{i t}$ is the Voting Premium of firm $\mathrm{i}$ in year $\mathrm{t}$ as defined in section $3.1 ; L 144 a_{i t}, L 1_{i t}$, $L 2 / 3_{i t}$ are dummy variables that take the value 1 if a firm cross-listed with a particular ADR program and 0 otherwise, $x_{i t}$ represent the firm level controls and $c_{i}$ denotes the country level 
controls. The coefficient of interest is $\gamma_{3}$, since among the ADR programs, only the Level 2 and 3 ADR listings subject firms to significant regulatory and disclosure standards.

Doidge finds that the coefficient $\gamma_{3}$ is negative and statistically significant, suggesting that Level 2/3 ADR listings have a significant negative effect on private benefits. In particular, Level $2 / 3$ cross-listed firms have a $43 \%$ smaller voting premium than noncrosslisted or Level 1 ADR / Rule 144a cross-listed firms. This finding is consistent with the bonding hypothesis, since the strenuous regulations and laws of the Level 2/3 ADRs limit the ability of controlling shareholders to appropriate value from minority shareholders.

Doidge also measures how the impact of cross-listings on private benefits varies with the level of home country investor protection, with differing types of ADRs (Level 2 vs. Level 3), and for firms that cross-list low vote shares compared to firms that cross-list highvote shares or all shares. Doidge finds that indeed the impact of cross-listings on private benefits varies with home country investor protection, consistent with the bonding hypothesis. However, there does not appear to be a difference between a Level 2 and Level 3 cross-listing. In addition, the change in private benefits is unaffected by the class of shares that is cross-listed (the high-vote class or the low-vote class).

Cross-listings and access to equity capital: Reese and Weisbach (2002) contains a number of findings concerning the relation between cross-listings and equity issues. First, they find that following a cross-listing, firms' propensities to issue equity increase. Comparing the quantities of equity issues by each firm during the two years before and after the cross-listing, Reese and Weisbach find that on average, firms issue $84 \%$ more equity after they have crosslisted in the United States. This effect is much larger for firms that are cross-listed on NYSE or NASDAQ, where regulatory requirements increase substantially, than for firms who trade over-the-counter or do a 144a offering, whose regulatory requirements are essentially unaffected. This fact suggests that there is no mechanical link between cross-listings and 
equity offerings, but that cross-listings are related with the extra shareholder protection associated with NYSE/NASDAQ listings.

Consistent with the bonding hypothesis, Reese and Weisbach also document that the increase in equity offerings following a cross-listing is larger for firms whose country of origin is less effective in protecting minority shareholders' interests. For example, the new issues of firms from French Civil Law countries with listings on NYSE/NASDAQ are 6.4\% and $32 \%$ respectively of the total frequency and the total value of all new issues from these countries, while the same statistics for the firms from English Common Law countries are $3.3 \%$ and $20.6 \%$. These results are verified in a multivariate context where the level of shareholder protection is measured not only by the judicial system, but also by direct measures of shareholder rights and accounting quality.

Finally, Reese and Weisbach document that following equity issues in the United States, firms from countries with weak shareholder protection tend to issue equity outside the United States in contrast to firms from countries with strong shareholder protection that issue equity predominately in the United States following cross-listings. For example, French Civil Law firms issue more than $62 \%$ of their new equity outside the United States following crosslistings in the United States, in contrast to English Common Law firms, who issue $65 \%$ of their new equity inside the United States following cross-listings. The same pattern also describes the value of these new equity issues. Again, these results are supported by a multivariate regression analysis. These findings suggest that the two groups of firms crosslist for different reasons; the French Civil Law firms cross-list to protect shareholders around the world, while English Common Law firms cross-list to gain access to U.S. capital markets. Cross-listings and stock price reaction: Evidence documenting positive stock-price reactions to the announcement of a cross-listing, is also consistent with the bonding hypothesis, among other explanations. While Karolyi (1998) surveys a number of such papers, perhaps the most 
recent study is Miller (1999). Consistent with previous work, Miller finds positive abnormal returns around the announcement date of a US cross-listing. More importantly however, the abnormal returns are much higher for NYSE/Nasdaq listed firms than for Rule 144a and Level 1ADR listed firms (2.63\% vs. $1.27 \%)$. One explanation for this difference is that investors take into consideration and appreciate the corporate governance restrictions to which exchange listed firms are subjected. In addition, Miller also finds that capital-raising listings (Level 3 ADRs) are associated with higher returns than non-capital raising exchange listings. The three-day average abnormal return of Level 3 ADRs is $3.23 \%$, compared to $1.83 \%$ for Level 2 ADRs. These results provide additional support for the bonding hypothesis to the extent that equity issuing ADRs are subject to somewhat more strict liability provisions than non-equity issuing ADRs. This finding is also noticeably in contrast to the usual negative stock price reaction to seasoned equity offerings, suggesting that extra information about shareholder protection is conveyed when a firm issues equity through an ADR, compared with a typical offering in the home country.

One puzzle emphasized by Stulz (1999) is that the short-term stock-price reactions to cross-listings documented by Miller (1999) and others are too small to explain the estimated drops in firms' cost of capital at the time of cross-listing. ${ }^{6}$ One possible answer to this puzzle is that methodological difficulties with event studies, especially regarding partial anticipation of the cross-listing, cause the short-term reaction to understate the complete reduction in the cost of capital. Foerster and Karolyi (1999) argue that a way of avoiding these difficulties is to focus on long-run rather than short-run abnormal returns when firms cross-list. Foerster and Karolyi document that in the year prior to a cross-listing, firms earn an abnormal return of about 19 percent, and in the year following the cross-listing, they earn an abnormal return

\footnotetext{
${ }^{6}$ Sarkissian and Schill (2003b) is the most recent in a long series of papers documenting a decrease on the cost of capital when a firm cross-lists. See Karoly (1998) for a detailed discussion of these papers.
} 
of 14 percent. These long-run returns are consistent with a decline in a firm's cost of capital around the time of the cross-listing.

\section{Summary}

The ability of managers to take resources from their firms as private benefits is an important factor in corporate finance because it has a large impact on the ability of firms' to raise external capital. A number of recent studies have estimated the average level of private benefit consumption across countries. These studies find that managers' ability to take private benefits from their firms differs dramatically across countries. The studies also find that the average level of private benefits is related to measures of shareholders' rights.

A natural response to this problem by a manager who wishes to raise capital is to commit somehow to protect the interests of his shareholders. Since making such a commitment is impossible in a legal environment that works against shareholder, Coffee (1999) proposed that shareholders in countries with poor protection can free-ride on the protections inherent in SEC registration by cross-listing in their stock in the United States. A number of papers have empirically examined the implications of this argument, and generally find evidence suggesting that such 'bonding' does occur and is one of a number of reasons why foreign firms cross-list their stocks in the United States.

Ultimately, as Shleifer and Vishny (1997) put it so well, the key question in corporate governance is why, when investors provide funds to a firm, they expect the firm's managers to give it back to them rather than expropriating it for the managers' own uses. The answer to this question varies across the world, leading to important differences in financing patterns. Private benefits are thus a key component of the system of corporate financing, which, as Rajan and Zingales (1998) emphasize, is a crucial determinant of an economy's growth and overall performance. As such, understanding more about private benefits' magnitude and the 
things that countries can do to affect this magnitude seems like an important topic for research. We have surveyed a number of recent papers on this topic. Given the inherent importance of the issue, in the near future we expect much more work on private benefits and voluntary, as well as government-imposed approaches to limit them. 


\section{References}

Barclay, M. and C. Holderness, 1989, The private benefits of control of public corporations, Journal of Financial Economics, 371-395.

Cantale, S., 1997, The choice of a foreign market as a signal, Unpublished working paper, INSEAD.

Coffee, J., 1999, The future as history: the prospects for global convergence in corporate governance and its implications, Northwestern Law Review, 93, 641-708.

Coffee, J. 2002, Racing Towards the Top? The Impact of Cross-Listings and Stock Market Competition on International Corporate Governance, Working Paper, Columbia University.

DeAngelo, H. and L. DeAngelo, 1985, Managerial ownership of voting rights: A study of public corporations with dual classes of common stock, Journal of Financial Economics, 14, 33-69.

Demsetz, H. and K. Lehn, 1985, The structure of corporate ownership: Causes and Consequences, Journal of Political Economy, 93, 1155-1177.

Desai, M., A. Dyck, and L. Zingales, 2003, Corporate Governance and Taxes, Working Paper, University of Chicago and Harvard Business School.

Doidge, C., 2003, U.S. Cross-Listings and the private benefits of control: Evidence from dual-class firms, Journal of Financial Economics, forthcoming.

Doidge, C., A. Karolyi, and R. Stulz, 2003, Why are foreign firms that are listed in the U.S. worth more? Journal of Financial Economics, forthcoming.

Dyck, A., 2002, The Hermitage Fund: Media and Corporate Governance in Russia, Harvard Business School Case N2-703-010.

Dyck, A. and L. Zingales, 2003a, Private benefits of control: An International Comparison, Journal of Finance, forthcoming.

Dyck, Alexander, and Luigi Zingales, 2003b, "The Corporate Governance Role of the Media," in Cornelius, Peter and Bruce Kogut (eds.) Corporate Governance and Capital Flows in a Global Economy, (New York: Oxford University Press).

Foerster, S. and A. Karolyi, 1999, The Effects of Market Segmentation and Investor Recognition on Asset Prices: Evidence from Foreign Stocks Listing in the United States, 54, Journal of Finance, 981-1013.

Jensen, M., 1993, The modern industrial revolution, exit, and the failure of internal control systems, The Journal of Finance, 48, 831-880. 
Karolyi, A., 1998, Why do companies list their shares abroad? A survey of the evidence and its implications Blackwell Publishers, Boston.

Lang, M., K. Lins and D. Miller, 2003, ADRs, Analysts, and Accuracy: Does cross-listing in the U.S. improve a firm's information environment and increase market value? Journal of Accounting Research, forthcoming.

La Porta, R., F. Lopez-de-Silanes, A. Shleifer, and R. Vishny, 1997, Legal determinants of external finance, Journal of Finance, 52, 1131-1150.

La Porta, R., Lopez-de-Silanes, F., Shleifer, A., Vishny, R., 1998. Law and finance. Journal of Political Economy 106, 1113-1155.

Licht, Amir N., 2003, Cross-Listing and Corporate Governance: Bonding or Avoiding, Chicago Journal of International Law, 4.

Lins, Karl, D. Strickland, and M. Zenner, 2003, Do Non-U.S. Firms Issue Equity on U.S. Exchanges to Relax Capital Constraints?, forthcoming, The Journal of Financial and Quantitative Analysis.

Lombardo, D. and M. Pagano, Law and equity markets; A simple model, Unpublished working paper, CSER and University of Salerno, Italy.

Mas-Colell, A., M. Whinston, and J. Green, 1995, Microeconomic Theory, Oxford University Press.

Miller P. D., 1999, The Market Reaction to International Cross-Listings: Evidence from Depositary Receipts, Journal of Financial Economics, 51, 103-123

Nenova, T., 2002, The value of corporate voting rights and control: A cross-country analysis, Journal of Financial Economics, forthcoming.

Pagano, M., A. Roell, and J. Zechner, 2002, The Geography of Equity Listing: Why do Companies list abroad? Journal of Finance, 57, 2651-2694.

Rajan, R. and L. Zingales, 1998, Financial Dependence and Growth, American Economic Review.

Reese, W.A., and M. Weisbach, 2002, Protection of minority shareholder interests, crosslistings in the United States, and subsequent equity offerings, Journal of Financial Economics, 66, 65-104.

Sarkissian, S. and M. Schill, 2003a, The Overseas Listing Decision: New Evidence of Proximity Preference, Review of Financial Studies, forthcoming.

Sarkissian, S. and M. Schill, 2003b, The Cost of Capital of Overseas Listings: Market Sequencing and Selection, Darden School Working Paper, 03-03.

Shleifer, A and R. Vishny, 1989, Management Entrenchment: The case of firm-specific investments, Journal of Financial Economics, 25, 123-140. 
Shleifer, A. and R. Vishny, 1997, A survey of corporate governance, Journal of Finance.

Siegel J., 2003, Can Foreign Firms Bond Themselves Effectively by Renting U.S. Securities Laws? working paper, Harvard Business School.

Stulz, R., 1999, Globilization of equity markets and the cost of capital, Journal of Applied Corporate Finance 12, 8-25.

Zingales, L, 1995, What determines the value of corporate votes? Quarterly Journal of Economics, 110, 1047-1073. 
Table 1

Samples Construction in Recent Studies of Private Benefits and Cross-Listings

\begin{tabular}{|c|c|c|c|c|}
\hline Paper & $\begin{array}{c}\text { Number of } \\
\text { Firms/Observations }\end{array}$ & Time Period & $\begin{array}{l}\text { Number of } \\
\text { Countries }\end{array}$ & Sources \\
\hline $\begin{array}{c}\text { Dyck-Zingales } \\
\text { (2003) }\end{array}$ & $\begin{array}{l}393 \text { Control } \\
\text { Transactions }\end{array}$ & $1990-2000$ & 39 & $\begin{array}{c}\text { SDC } \\
\text { Datastream }\end{array}$ \\
\hline Doidge (2003) & 745 dual-class firms & 1994-2001 & 20 & $\begin{array}{c}\text { Datastream, } \\
\text { FISonline, Extel, } \\
\text { Moody's }\end{array}$ \\
\hline $\begin{array}{c}\text { Nenova } \\
(2002)\end{array}$ & 661 dual class firms & $\begin{array}{c}\text { Jan. 1- Dec. } 31 \\
1997\end{array}$ & 18 & Datastream \\
\hline $\begin{array}{c}\text { Doidge- } \\
\text { Karolyi-Stulz } \\
(2003)\end{array}$ & $\begin{array}{l}714 \text { cross-listed } \\
\text { firms, } 4078 \text { non } \\
\text { cross-listed firms }\end{array}$ & Dec. 31,1997 & 40 & Worldscope \\
\hline $\begin{array}{l}\text { Reese- } \\
\text { Weisbach } \\
(2002)\end{array}$ & $\begin{array}{c}2038 \text { cross-listed } \\
\text { firms, } 1051 \text { firms } \\
\text { with firm-specific } \\
\text { data }\end{array}$ & $\begin{array}{c}\text { Jan. } 1985 \text { - } \\
\text { June } 1999\end{array}$ & 45 & $\begin{array}{c}\text { SDC, Bank of } \\
\text { New York } \\
\text { website, CRSP }\end{array}$ \\
\hline
\end{tabular}


Table 2

Approaches to Estimating Private Benefits of Control

\begin{tabular}{|c|c|}
\hline Paper & Raw Measures of Private Benefits \\
\hline $\begin{array}{c}\text { Dyck-Zingales } \\
(2003)\end{array}$ & $\begin{array}{l}\text { Block Premium }=\lambda B_{b}+(1-\lambda) B_{s}-\alpha(1-\lambda)\left(Y_{b}-Y_{s}\right) \\
B_{b, s}: \text { level of private benefits extracted by the buyer (seller) } \\
Y_{b, s}: \text { per share cash flow benefits generated by the buyer (seller) } \\
\lambda: \text { seller's bargaining power (between } 0 \text { and } 1) \\
\alpha \text { : size of control block of shares, normalized between } 0 \text { and } 1\end{array}$ \\
\hline Doidge (2003) & $\begin{array}{l}\text { Voting Premium }=\left(\mathrm{P}_{\mathrm{H}}-\mathrm{P}_{\mathrm{L}}\right) /\left(\mathrm{P}_{\mathrm{L}}-\mathrm{rv} * \mathrm{P}_{\mathrm{H}}\right) \\
\mathrm{P}_{\mathrm{H}}, \mathrm{P}_{\mathrm{L}} \text { : weekly local market closing prices of high and low voting shares } \\
\text { rv: relative number of votes attached to the low voting shares (between } 0 \\
\text { and 1) }\end{array}$ \\
\hline Nenova (2003) & $\begin{array}{l}V C B V=\left[\mathrm{P}_{M}(\mathrm{t})-\mathrm{P}_{\mathrm{L}}(\mathrm{t})\right] /(1-\mathrm{k}) *\left(\left[\mathrm{~N}_{\mathrm{M}}+\mathrm{N}_{\mathrm{L}} * \mathrm{k}\right] / 2\right) /\left[\mathrm{N}_{\mathrm{M}} * \mathrm{P}_{\mathrm{M}}(\mathrm{t})+\mathrm{N}_{\mathrm{L}} * \mathrm{P}_{\mathrm{L}}(\mathrm{t})\right] \\
\text { VCBV: Value of Control Block Votes } \\
\mathrm{P}_{\mathrm{M}}(\mathrm{t}), \mathrm{P}_{\mathrm{L}}(\mathrm{t}) \text { : weekly prices of multiple and limited voting shares } \\
\mathrm{N}_{\mathrm{M}}, \mathrm{N}_{\mathrm{L}} \text { : number of multiple and limited voting shares } \\
\mathrm{k} \text { : ratio of voting power of a limited voting share to a multiple voting } \\
\text { share. }\end{array}$ \\
\hline
\end{tabular}


Table 3

Alternative Estimates of Country Average Private Benefits of Control

\begin{tabular}{|c|c|c|c|}
\hline Country & $\begin{array}{l}\text { Nenova } \\
\text { (Country-dummy } \\
\text { coefficients) }\end{array}$ & $\begin{array}{c}\text { Doidge } \\
\text { (Raw measure) }\end{array}$ & $\begin{array}{l}\text { Dyck-Zingales } \\
\text { (Country-dummy } \\
\text { coefficients) }\end{array}$ \\
\hline Argentina & ----- & ----- & $18.3 \%$ \\
\hline Australia & $23.2 \%$ & $15.5 \%$ & $5.4 \%$ \\
\hline Brazil & $23.19 \%$ & $25.3 \%$ & $65.5 \%$ \\
\hline Canada & $2.7 \%$ & $11.9 \%$ & $-5.9 \%$ \\
\hline Chile & $23.14 \%$ & $8.5 \%$ & $16 \%$ \\
\hline Colombia & ----- & $29.5 \%$ & $28.2 \%$ \\
\hline Czech Republic & ----- & ------ & $56.3 \%$ \\
\hline Denmark & $0.84 \%$ & $8.8 \%$ & $2.8 \%$ \\
\hline Egypt & ----- & ------ & $7.7 \%$ \\
\hline Finland & $-5 \%$ & $7.2 \%$ & $-0.2 \%$ \\
\hline France & $28 \%$ & $40.4 \%$ & $7.6 \%$ \\
\hline Germany & $9.5 \%$ & $15.5 \%$ & $3.8 \%$ \\
\hline Hong Kong & $-2.9 \%$ & ----- & $3.9 \%$ \\
\hline Indonesia & ----- & ----- & $4.2 \%$ \\
\hline Israel & ----- & ----- & $25.4 \%$ \\
\hline Italy & $29.4 \%$ & $49.1 \%$ & $32.3 \%$ \\
\hline Japan & ----- & ----- & $-3.2 \%$ \\
\hline Malaysia & ----- & ----- & $9 \%$ \\
\hline Mexico & $36.4 \%$ & $0.8 \%$ & $34.8 \%$ \\
\hline Netherlands & ----- & ----- & $-2.5 \%$ \\
\hline New Zealand & ----- & ----- & $2.7 \%$ \\
\hline Norway & $5.83 \%$ & $4.2 \%$ & $6 \%$ \\
\hline Peru & ----- & ----- & $7.6 \%$ \\
\hline Phillipines & ----- & ----- & $14.7 \%$ \\
\hline Poland & ----- & ----- & $4.5 \%$ \\
\hline Portugal & ----- & $4.3 \%$ & $20.4 \%$ \\
\hline Singapore & ----- & ----- & $4.6 \%$ \\
\hline South Africa & & $7.6 \%$ & $-1.4 \%$ \\
\hline South Korea & $28.94 \%$ & $67 \%$ & $12.8 \%$ \\
\hline Spain & ----- & ----- & $5.8 \%$ \\
\hline Sweden & $1.04 \%$ & $4.5 \%$ & $4.4 \%$ \\
\hline Switzerland & $5.44 \%$ & $16.2 \%$ & $-5.4 \%$ \\
\hline Taiwan & ----- & ----- & $-3.8 \%$ \\
\hline Thailand & ----- & ----- & $11.1 \%$ \\
\hline Turkey & ----- & ----- & $36.4 \%$ \\
\hline United Kingdom & $9.5 \%$ & $15.7 \%$ & $2.9 \%$ \\
\hline United States & $2 \%$ & ----- & $3.7 \%$ \\
\hline Venezuela & ----- & $13.4 \%$ & $23.4 \%$ \\
\hline
\end{tabular}




\section{Table 4}

\section{Regulatory Implications of Cross-Listing}

Panel A: Disclosure Requirements

\begin{tabular}{|c|l|}
\hline Type of listing & $\begin{array}{l}\text { Financial Reporting and } \\
\text { disclosure requirements }\end{array}$ \\
\hline $\begin{array}{l}\text { Rule 144a- } \\
\text { Level 1 ADR } \\
\text { program }\end{array}$ & $\begin{array}{l}\text { Exempted from the US reporting } \\
\text { requirements }\end{array}$ \\
\hline $\begin{array}{l}\text { Level } 2 \text { or 3 } \\
\text { ADR program }\end{array}$ & $\begin{array}{l}\text { Reconciliation with US GAAP accounting } \\
\text { rules concerning disclosure of non-financial } \\
\text { items (e.g. ownership, executive } \\
\text { compensation). Subject to insider trading } \\
\text { rules, tender offer rules, "going private" } \\
\text { rules. }\end{array}$ \\
\hline
\end{tabular}


1) Section 13(d) of the Securities Exchange Act of 1934 requires any person or group beneficially owning at least $5 \%$ of any equity security to file a report within five days of when the $5 \%$ threshold is crossed. This $5 \%$ threshold is noticeably smaller than the $10 \%$ that is required by the European Community's Transparency Directive and clearly has a large impact on takeover strategies and their implications for small shareholders.

2) Under Section 14(d) of the Exchange Act, all tender offers for corporations registered with the S.E.C. have to comply with U.S. disclosure and procedural rules. These rules would apply if one European company makes an offer for a second European company that has an ADR in the U.S., even if the shares traded in the U.S. amount to less than one percent of the outstanding shares. An important aspect of these procedural rules is that each shareholder of a particular class has the right to participate in any tender offer and to receive the best price paid to any other shareholder pursuant to the tender offer. Registering in the U.S. thus substantially increases the rights of shareholders of non-U.S. firms when faced with a tender offer.

3) Firms cross-listing on a U.S. exchange are subject to most of the rules of the exchange regarding corporate governance. [See Table 1 of Reese and Weisbach (2002)]

4) The S.E.C. is granted authority under Section 13(e) of the Exchange Act to regulate the treatment of minority shareholders in "going private" transactions.

5) Under the Foreign Corrupt Practices Act, all registered U.S. corporations are required to keep books and records that fairly reflect the transactions of the issuer. The purpose of this law is to prevent corporations from engaging in bribery or similar practices.

6) Rule 10b-5 gives shareholders the right to sue for losses ensued because of fraudulent statements made by a company whose equity they own. Listing in the United States subjects foreign companies to this rule, and allows them to be sued in the United States for fraudulent statements made anywhere in the world.

7) All accounting statements must conform to U.S. GAAP. 
Table 5

Number of Cross-Listings in 1986, 1991 and 1997 (End of Year Values)

Table 5 describes the European and US cross-listings in 1986, 1991 and 1997. For each exchange, the table displays the number of foreign cross-listed firms by country of origin. Each cell contains three values: the top one provides cross-listings for 1986, the middle for 1991, and the bottom for 1997. This table is taken from Pagano et al. (2002). 
Table 5 (continued)

Country of Origin

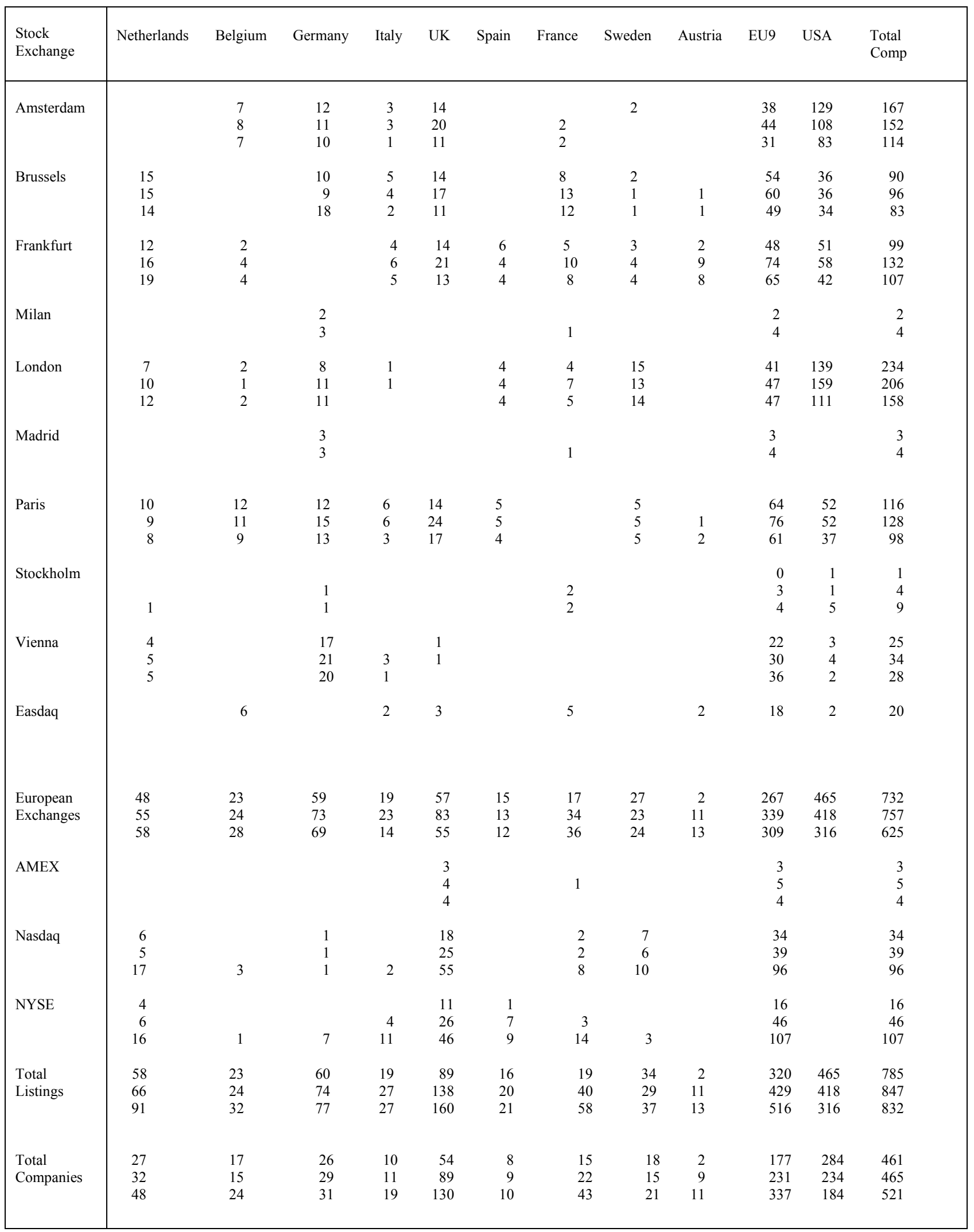


Table 6

Theoretical Predictions of the Bonding Argument

\begin{tabular}{|l|l|}
\hline $\begin{array}{l}\text { Cross-listings } \\
\text { and shareholder } \\
\text { protection. }\end{array}$ & $\begin{array}{l}\text { The predicted relation between level of protection in home country and } \\
\text { quantity of cross-listings in the US is ambiguous. }\end{array}$ \\
\hline $\begin{array}{l}\text { Cross-listings } \\
\text { and firm value. }\end{array}$ & $\begin{array}{l}\text { The value of cross-listed firms should be higher than similar non-cross-listed } \\
\text { firms. }\end{array}$ \\
\hline $\begin{array}{l}\text { Cross-listings } \\
\text { and private } \\
\text { benefits. }\end{array}$ & $\begin{array}{l}\text { The difference in value between cross-listed and non-cross-listed firms should be } \\
\text { negatively related to shareholder protection in the home country. }\end{array}$ \\
$\begin{array}{l}\text { The difference in private benefits between cross-listed and non-cross- } \\
\text { listed firms should be negatively related to the quality of shareholder } \\
\text { protection in the home country. }\end{array}$ \\
$\begin{array}{l}\text { The price of both the high-vote and the low-vote shares should increase } \\
\text { and access to } \\
\text { equity capital. } \\
\text { following a cross listing. However, the price of a low voting share should } \\
\text { increase by a higher amount, leading to a decrease in the voting } \\
\text { premium. }\end{array}$ \\
$\begin{array}{l}\text { Firms with weak shareholder protection in their home countries are more } \\
\text { likely to issue equity following a cross-listing. }\end{array}$ \\
$\begin{array}{l}\text { Firms from countries with strong protection for minority shareholders are } \\
\text { more likely to issue equity in the US whereas firms from countries with } \\
\text { weak protection are more likely to issue equity at home or in a third } \\
\text { country. }\end{array}$ \\
\hline
\end{tabular}




\section{Table 7}

\section{Empirical Results}

\begin{tabular}{|c|c|}
\hline $\begin{array}{l}\text { Cross-listings } \\
\text { and Shareholder } \\
\text { Protection } \\
\text { (Reese-Weisbach } \\
\text { 2002) }\end{array}$ & $\begin{array}{l}\text { No clear empirical relation between the quantity of cross-listings } \\
\text { and level of shareholder protection at home. Univariate statistics } \\
\text { show that } 10.1 \% \text { of firms from French Civil Law countries cross- } \\
\text { list in the United States versus } 7.4 \% \text { of firms from English } \\
\text { Common Law countries. Multivariate analysis results suggest the } \\
\text { opposite. }\end{array}$ \\
\hline $\begin{array}{l}\text { Cross-listings } \\
\text { and Firm Value } \\
\text { (Doidge-Karolyi- } \\
\text { Stulz, 2003) }\end{array}$ & $\begin{array}{l}\text { Firms listed in the US have a } q \text { ratio that is } 16.5 \% \text { higher than the } \\
q \text { ratios of firms from the same country that do not cross-list in the } \\
\text { U.S. } \\
\text { The cross-listing premium is larger for exchange listings ( } 36.5 \%) \\
\text { than Rule } 144 \text { a and Level } 1 \text { ADR listings ( } 14.2 \% \text { and } 4.5 \% \\
\text { respectively). } \\
\text { The cross-listing premium is also larger for firms from countries } \\
\text { with weak shareholder protection. }\end{array}$ \\
\hline $\begin{array}{l}\text { Cross-listings } \\
\text { and Private } \\
\text { Benefits } \\
\text { (Doidge 2003) }\end{array}$ & $\begin{array}{l}\text { Cross-listing via a Level } 2 / 3 \text { ADR in the US increases minority } \\
\text { shareholder protection and reduces the private benefits. } \\
\text { Firms that cross-list have voting premiums that are } 43 \% \text { lower } \\
\text { than those of non-cross-listed firms. } \\
\text { The negative impact of cross-listings on voting premium is larger } \\
\text { for firms from countries with weak shareholder protection. }\end{array}$ \\
\hline $\begin{array}{l}\text { Cross-listings } \\
\text { and Access to } \\
\text { Equity Capital } \\
\text { (Reese-Weisbach } \\
\text { 2003) }\end{array}$ & $\begin{array}{l}\text { There is a large increase ( } 84 \%) \text { in both the number and value of } \\
\text { equity offerings following cross-listings. } \\
\text { Firms from countries with weak shareholder protection than firms } \\
\text { from countries with strong protection to issue equity following } \\
\text { their cross-listing. } \\
\text { Firms from countries with weak protection issue equity in larger } \\
\text { quantities than firms from countries with strong protection. } \\
\text { Firms from countries with strong protection are more likely to } \\
\text { issue equity in the US following a cross-listing. Firms from } \\
\text { countries with weak shareholder protection are more likely to issue } \\
\text { equity outside the U.S. following a cross-listing in the U.S. }\end{array}$ \\
\hline
\end{tabular}

